\title{
Experimental Results Regarding the Groundwater Quality in Bacau City, Romania
}

\begin{abstract}
OANA TIRTOACA (IRIMIA) ${ }^{1}$, MIRELA PANAINTE LEHADUS ${ }^{1 *}$, VALENTIN NEDEFF ${ }^{1,2, *}$, ION SANDU ${ }^{3,4}$, CLAUDIA TOMOZEI $^{1}$, VASILE VALENTIN CRETU ${ }^{5}$, ANDREI VICTOR SANDU $4,6 *$

${ }^{1}$ Vasile Alecsandri University of Bacau, Faculty of Engineering, 157 Calea Marasesti, 600115, Bacau, Romania

${ }^{2}$ Gheorghe Ionescu Sisesti, Academy of Agricultural and Forestry Sciences Bucharest, 61 Marasti Blvd., 011464 Bucharest, Romania

${ }^{3}$ Alexandru Ioan Cuza University of Iasi, Arheoinvest Interdisciplinary Platform, Scientific Investigation Laboratory, 11 Carol I Blvd., 700506, Iasi, Romania

${ }^{4}$ Romanian Inventors Forum, 3 Sf. Petru Movila Str., Bloc L11, III/3, 700089, Iasi, Romania

${ }^{5}$ Gheorghe Asachi Technical University of Iasi, Hydrotechnical, Geodesy and Environment Faculty, 65 D. Mangeron Blvd., 700050, Iasi, Romania

${ }^{6}$ Gheorghe Asachi Technical University of lasi, Materials Science and Engineering Faculty, 53A D. Mangeron Blvd., 700050, lasi, Romania

The state of groundwater in terms of quality and quantity are a fundamental importance in urban areas. This paper aims to identify qualitative status of groundwater in Bacau city. To determine groundwater quality in Bacau city were taken samples from ten sources. Physico-chemical parameters chosen for making determinations are represented by ammonium, magnesium, manganese, nitrite and total nitrogen. After performing of measurements, it was observe that the admissible limit values of water quality parameters were exceeded in all ten sampling points. It has been established so that any source of groundwater in Bacau is not recommend for human consumption. In this regard, it is recommended to order measures by the competent authorities for the safety and health of the population.
\end{abstract}

Keywords: water quality, pollution, groundwater

Water represent an essential element of life, constituting an important factor that balances ecosystems. The knowledge of water quality, if we refer to water for consume or wastewater, is strictly necessary because affects human and animal health, life cycle of vegetation and anthropic activities [1-15].

The water supply of cities it has become a major concern, especially in recent decades. Research has shown that groundwater is a significant source of drinking water for cities because of its abundance, stable quality and reasonable exploitation costs [13, 14]. Groundwater in urban zones plays a major but often unappreciated role in the social and economic wellbeing being use for domestic, commercial and industrial purposes [13, 15-23]. Groundwater quality in urban areas is compromised primarily by human activities as well industrial activities and the uncontrolled leakage of wastewater and septic tanks, irrigation of green spaces, improper waste management or may be due to urban storm water infiltration [14, 16, 24].

In recent decades attention was given to the study on groundwater quality in urban areas. This kind of study was conducted by Nasrabadi and Abbasi Maedeh referring to groundwater quality in the city of Tehran, Iran [25]. In their study, the authors analyzed ten water quality parameters for nine sampling points. Following investigations, it was established that only five of the nine sources analyzed characteristics are acceptable for drinking or in agriculture [25]. Also, after the research could be established sources of pollution, which are represented by the agriculture developed in the extra-urban leakages from the sewage netw ork or septic tanks [25].

Ferral et al. have conducted a research related to groundwater quality in Cordoba, Argentina, a city that uses ground water only in industry, not for the population consumption [26]. The main sources of groundwater pollution in Cordoba are represented by urban storm water, urban wastewater and solid waste disposal sites [26]. Analyses revealed that in industrial areas arsenic, nitrates, fluorine, bacteria coliforms exceed the maximum limits. Also analyzes showed that urban storm waters contain a very high concentrations of TSS, BOD, COD, $\mathrm{N}-\mathrm{NH}_{4}^{+}$, $\mathrm{N}-\mathrm{NO}_{3}^{-}$and $\mathrm{PO}_{4}{ }^{-}[26]$.

An extensive study on groundwater quality in urban areas was conducted in Dar es Salaam, Tanzania where approximately $42 \%$ of the inhabitants from urban areas depends on underground water supplies [26]. The city where the study was conducted, has the main sources of groundwater pollution: industrial effluents, domestic wastes and leachate from solid wastes disposal sites [26]. After analysis it is found that more than $45 \%$ of the analyzed samples exceed the national values for nitrate, chorine and fecal coliform. In about $25 \%$ of the samples were identified petroleum hydrocarbons, especially polycyclic aromatic hydrocarbons (PAHs) [27].

This paper aims to identify the qualitative status of groundwater in Bacau city, Romania. The main sources of groundwater pollution in Bacau are represented by industrial pollution, agricultural activities developed around the city of Bacau, ex-filtration of existing sewerage networks, rainwater, etc. [28]. Sampling of water was carried out in ten points of capture. To determine groundwater quality in Bacau were made determinations for the following parameters: ammonium $\left(\mathrm{NH}_{4}^{+}\right)$, magnesium $(\mathrm{Mg})$, manganese $(\mathrm{Mn}$,$) nitrites \left(\mathrm{NO}_{3}^{-}\right)$, total nitrogen.

Kurosawa et al. [29] claim that ammonium not harm human health if the $\mathrm{pH}$ of water falls between 6.5 to $9.5 \mathrm{pH}$

* email: mirelap@ub.ro; vnedeff@ub.ro; euroinvent@yahoo.co 
units. In the case of exceeding the limit allowed by the legislation in force, i.e. $0.50 \mathrm{mg} / \mathrm{L}$, are identified digestive disorders, skin lesions, eye irritation, bone problems.

Studies have shown that the presence of magnesium in the water provides the water hardness, which is a risk factor for cardiovascular diseases, the development of blood pressure and digestive disorders. According to the legislation, the maximum permissible quantity of magnesium is $50 \mathrm{mg} / \mathrm{L}$ [ 30 ].

The presence of manganese in water intended for human consumption is accepted in limit of $0.05 \mathrm{mg} / \mathrm{L}$, according to the law [31]. At concentrations greater than $0.05 \mathrm{mg} / \mathrm{L}$ water containing manganese adversely affects the airways. According to some studies in Japan excess manganese in water can cause encephalitis (if manganese exceeds a concentration of $14 \mathrm{mg} / \mathrm{L}$ ) [31].

Their excess leads to the formation of methemoglobin and hence the and hence the dominant symptoms in a disease called methemoglobinemia with predominant symptoms in children and infants fed with artificial milk formula and mixed, as well as to formation of nitrosamines due to the reaction with secondary or tertiary amines, cancerogenic action unanimously recognized. Because of the harmful effect, the maximum permissible concentration of nitrates in drinking water is $0.5 \mathrm{mg} / \mathrm{L}[32$, 33].

The presence of excess nitrogen leads to excessive aquatic plant growth that may block underground water intakes. The high content of nitrogen in the body can cause respiratory problems. According to current legislation, the maximum permissible concentration is $0.50 \mathrm{mg} / \mathrm{L}[16,29$, 34].

Admissible limit values were establish by reference to the Law no. 458 of 8 July 2002 regarding drinking water quality, republished, as amended [35].

The present paper aims to identify the groundwater quality status in Bacau city, Romania for some key parameters.

\section{Experimental part}

City of Bacau is Bacau county seat (Fig. 1) and is located in North East Romania, on the coordinates $46^{\circ}$ and $35^{\prime}$ north latitude and $26^{\circ}$ and $55^{\prime}$ east longitude [10]. Bacau municipality's water resources consist of surface water inland rivers, natural and artificial lakes and in a lesser extent in groundwater $[10,24]$. Drinking water supply of Bacau is a source of surface water (Lake Poiana Uzului located approximately $50 \mathrm{~km}$ west of town) and the underground water source (six collection fronts are in localities situated near the city of Bacau: fronts capture Gheraiesti 1 and 2; fronts capture Margineni 1 and 2 and fronts capture Hemeius 1 and 2) [10, 24].

The phreatic pollution is most often an almost irreversible phenomenon and has serious consequences for the use of underground reserve water supply, depollution of groundwater water sources being a difficult process [10]. Risks of pollution on groundwater from Bacau resulting mainly from ex-filtration existing sewage networks, as a result of pipes broken, imperfect connections and corrosion other structures of the network, accidental pollution resulting from industrial, agricultural activities carried around Bacau, deposits of raw materials, finished products, ancillary products, storage of non-conforming wastes, units that produce diffuse pollution accidents, abandoned industrial sites [10].

Water sampling was done using hand pumps placed in different areas of the city of Bacau. These pumps were made in the early 1950's with the role of local water resources and firefighting [16]. At the time of sampling (J une 2015) water was used for domestic activities (Regional Operating Company Bacau then cease current water because of damages) or for gardening. In Figure 2 is presented the city of Bacau location and the ten points where samples were taken [25].

For each of the ten points of the sample, was determined following water quality parameters: ammonium, magnesium, manganese, total nitrogen and nitrite. Laboratory equipment used to determine groundwater quality in the city of Bacau is the Nova 60 photometer and thermoreactor TR 320.

\section{Results and discussions}

From measurements for determining groundwater quality in the city of Bacau, regarding the ammonium parameter it can be observed permissible limit value was exceeded only sampling point located on Cornisa no. 8 (Fig. 3). In the other nine sampling points other overruns were not identified.

Also, for determinations concerning drinking water quality for parameter magnesium it can be notice that the allowed limit value was exceeded in only one sampling point, namely the one on Republicii street (Fig. 4). In the other nine sampling points, other overruns were not identified.

Regarding drinking water quality indicator of manganese, were identified two sampling points where
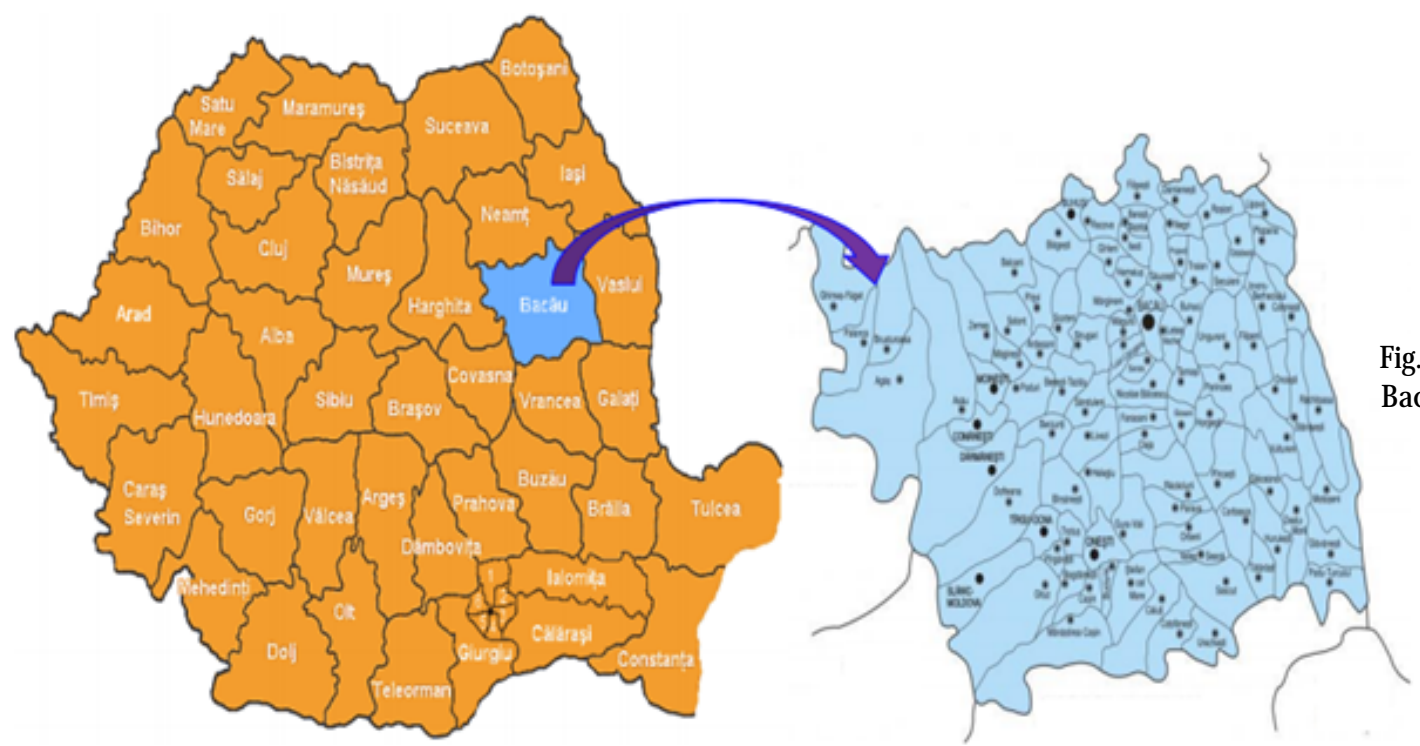

Fig. 1. Image with positions of Bacau county in Romania [10] 


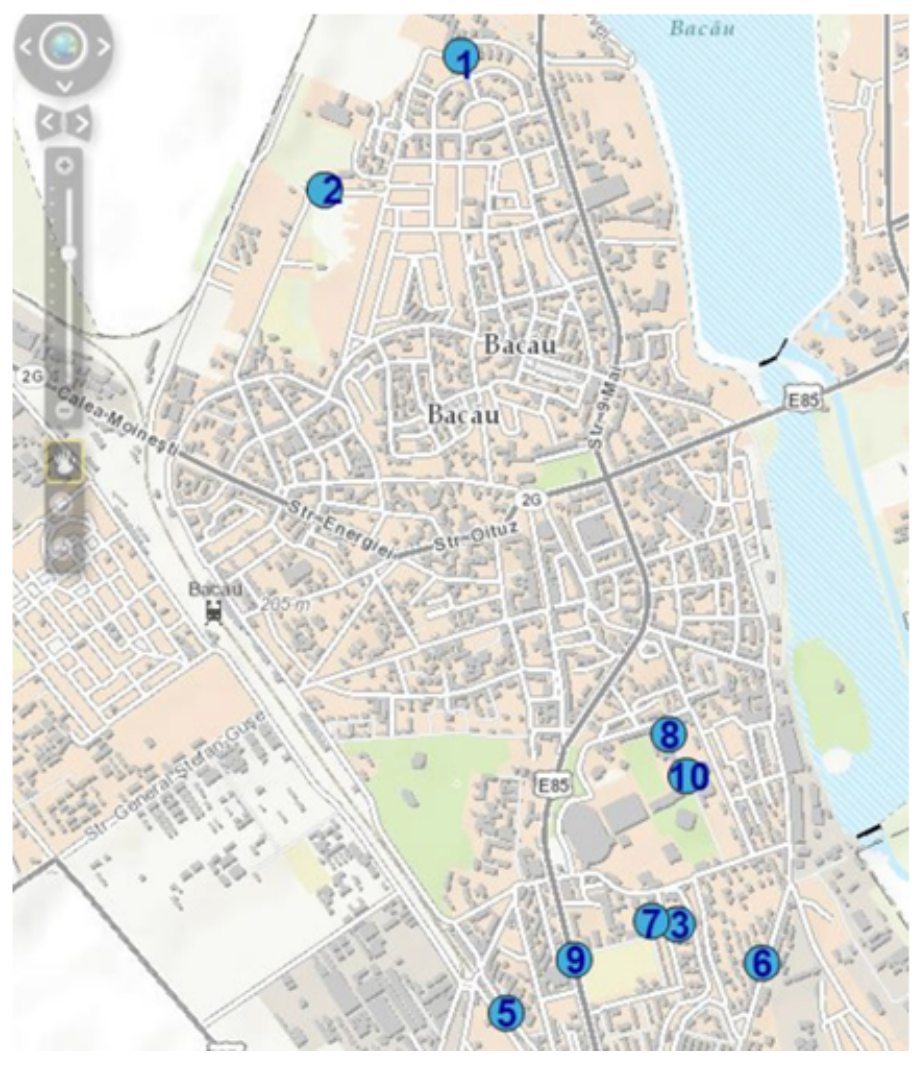

Fig. 2. Sampling points for groundwater in Bacau city [25]

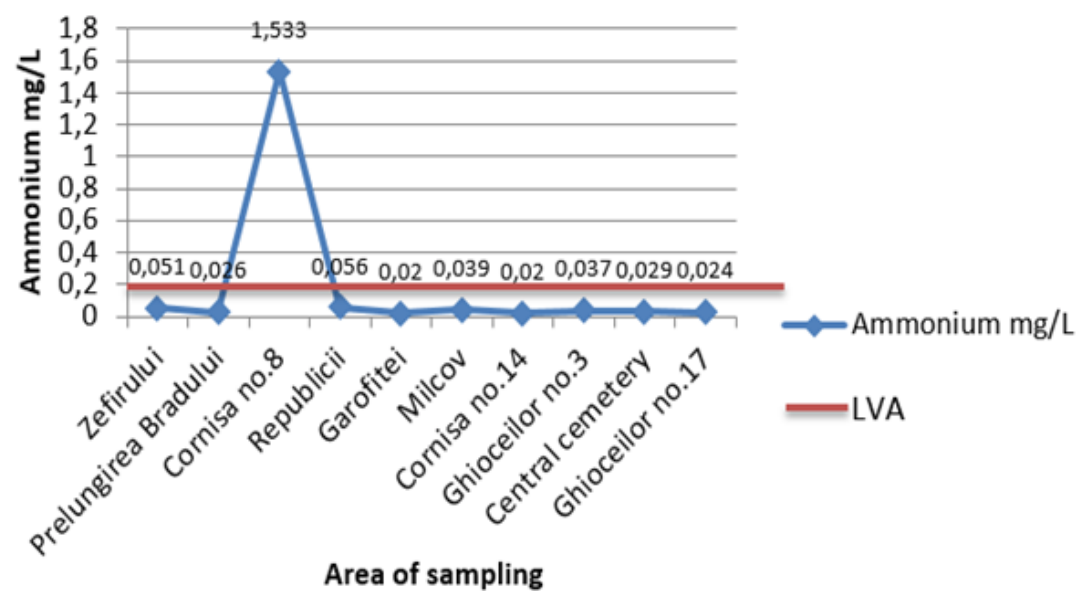

Fig. 3. Graphical representation of ammonium value from groundwater in city of Bacau

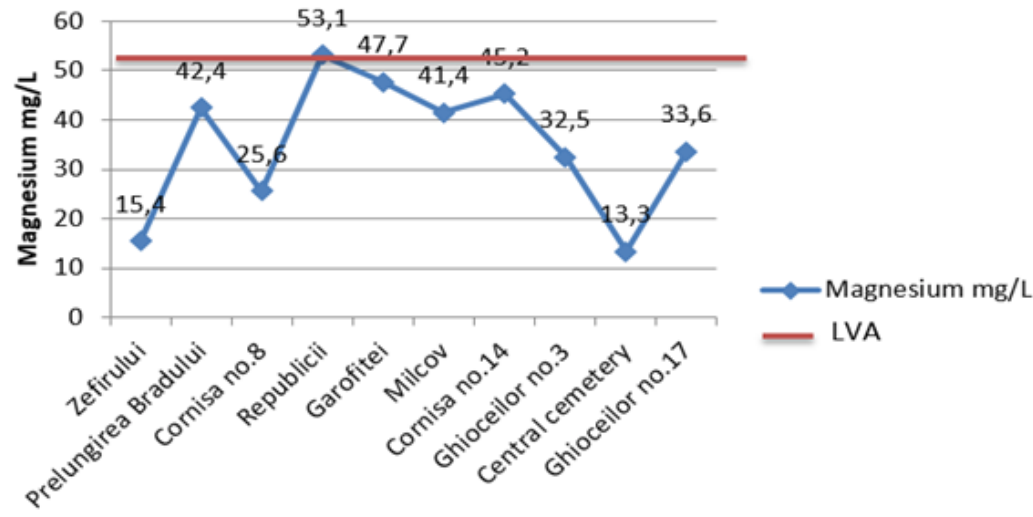

Fig. 4. Graphical representation of magnesium value from groundwater in city of Bacau

\section{Area of sampling}

the maximum permissible norms are exceeded, on Zefirului street and Cornisa no. 8 street (Fig. 5). In the other eight sampling points other overruns were not identified.

Following the laboratory measurements for quality parameter nitrite, permissible limit value was exceeded at the pump in Garofiei street. No were exceeded permissible limit values for parameter nitrite on the following streets: Republicii, Milcov, Cornisa no. 4, Zefirului, Prelungirea Bradului, Corni'a no. 8, Ghioceilor no. 3, Central cemetery and Ghioceilor no. 17 (Fig. 6).

After the measurements made for drinking water quality, regarding the indicator nitrogen permissible limitvalue was exceeded at all pumps that have been sampled (Fig. 7). 

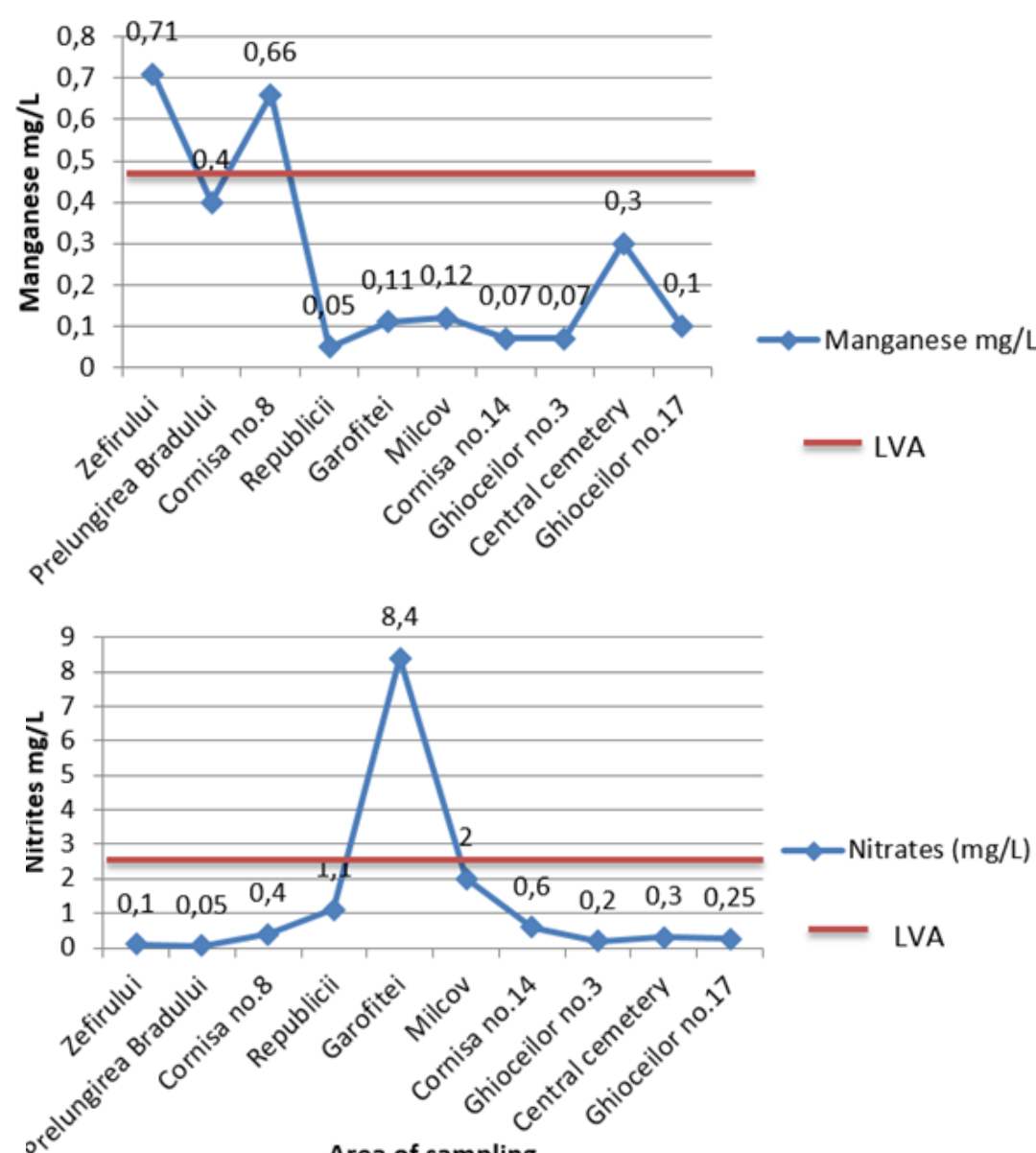

Area of sampling

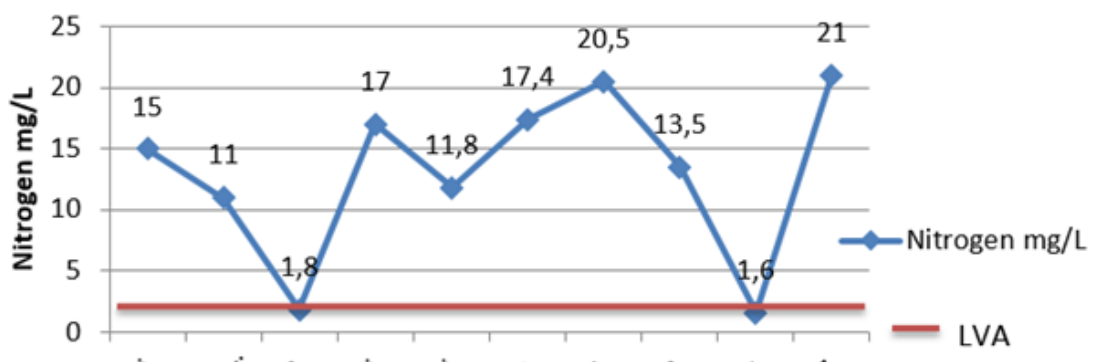

Fig. 5. Graphical representation of manganese value from groundwater in city of Bacau
Fig. 6. Graphical representation of nitrites value from groundwater in city of Bacau
Fig. 7. Graphical representation of nitrogen value from groundwater in city of Bacau

street. For parameter nitrites the sampling point was identified on Garofitei street and the value of parameter was $8.4 \mathrm{mg} / \mathrm{L}$.

-For manganese were identified two sampling points

\section{Conclusions}

Groundwater represent a resource of drinking water supply to the population for sustainable development at local and regional level. Because of the ability to filter and self-cleaning of the geological environment, groundwater is generally a resource of good quality and can provide long-term exploitation.

An active source of pollution to groundwater in this area is represent by the industry developed in Bacau city.

The research carried out in 2015 with regard to the quality of groundwater for five indicators (ammonium, magnesium, manganese, total nitrogen and nitrite) in Bacau city emphasized the following aspects:

-Regarding the parameters ammonium, magnesium and nitrates it can be notice that among ten sampling points, the allowed limit value was exceeded in only one sampling point. For ammonium the sampling point was located on Cornisa no. 8 and the value of parameter was $1.533 \mathrm{mg} / \mathrm{L}$. Regarding the magnesium the value exceeded was $53.1 \mathrm{mg} / \mathrm{L}$ and the sampling point was Republicii where the maximum permissible norms are exceeded, on Zefirului street $(0.71 \mathrm{mg} / \mathrm{L})$ and Cornisa no. 8 street $(0.66$ $\mathrm{mg} / \mathrm{L})$.

-For nitrogen parameter, permissible limit value $(0.5 \mathrm{mg} /$ L) was exceeded in all pumps that have been sampled (with values between $1.6-21 \mathrm{mg} / \mathrm{L}$ ).

Following the determinations made five indicators of water quality sampling points taken from ten samples analysed, it can be seen as not suitable for human consumption.

\section{References}

1.IRIMIA, O., TOMOZEI, C., PANAINTE, M., MOSNEGUTU, E.F., BARSAN, N., Environmental Engineering and Management Journal, 12, no. 1, 2013, p. 35.

2.BARSAN, N., NEDEFF, V., TEMEA, A, MOSNEGUTU, E., CHITIMUS, A.D., TOMOZEI, C., Chemistry J ournal of Moldova, 12, no. 1, 2017, p. 61. 
3.TATARU, L., NEDEFF, V., BARSAN, N., MOSNEGUTU, E., PANAINTELEHADUS, M., SANDU, I., CHITIMUS, D., Mat. Plast., 55, no. 4, 2018, p. 660.

4.TATARU, L., NEDEFF, V., BARSAN, N., PANAINTE-LEHADUS, M., MOSNEGUTU, E., CHITIMUS, D., FABIAN, F., J ournal of Engineering Studies and Research, 24, no. 2, 2018, p. 46.

5.COCHIORCA, A., NEDEFF, V., BARSAN, N., MOSNEGUTU, E.F., PANAINTE-LEHADUS, M., TOMOZEI, C., Food Industry, 19, no. 4, 2018, p. 455.

6.COCHIORCA, V. NEDEFF, N. BARSAN, M. PANAINTE-LEHADUS, E. F. MOSNEGUTU, Aspects related to water quality assessment in a mining activity area. Case study, mining area Tg. Ogna, Romania, Proceeding of the International Multidisciplinary Scientific GeoConference Surveying Geology and Mining Ecology Management, SGEM, 18, (3.1), 2018, p. 87.

7.FABIAN, F., NEDEFF, V., BIRSAN, N., MOSNEGUTU, E., Rev. Chim. (Bucharest), 70, no. 3, 2019, p. 881.

8.TATARU, L., NEDEFF, V., BARSAN, N., SANDU, A.V., MOSNEGUTU, E., PANAINTE-LEHADUS, M., SANDU, I., Mat. Plast., 56, no. 1, 2019, p. 97 9.MISAILA, L., NEDEFF, F.M., BARSAN, N., SANDU, I.G., GROSU, L., PATRICIU, O.I., GAVRILA, L., FINARU, A.L., Rev. Chim.(Bucharest), 70, no. 6, 2019, p. 2212

10.TURCU, M., BARSAN, N., MOSNEGUU, E., DASCALU, M., CHITIMUS, D., RADU, C., Environmental Engineering and Management Journal, 15, no. 32016 , p. 521

11.FABIAN, F., NEDEFF, V., PANAINTE - LEHADUS, M., BARSAN, N. IRIMIA, O, RACOVITA, S., J ournal of Engineering Studies and Research, 22, no. 3, 2016, p. 34

12.TURCU, M., BARSAN, N., IRIMIA, O., JOITA, I., BELCIU, M. Environmental Engineering and Management J ournal, 13, no. 7, 2014, p. 1751.

13.MUDD, G.M., DELETIC, A., FLETCHER, T.D., WENDELBORN, A., A Review of Urban Groundwater in Melbourne: Considerations for WSUD. Water sensitive urban design, 2014, p. 428.

14.VAZQUEZ-SUNE, E., CARRERA, J., TUBAU I., SANCHEZ-VILA, X. SOLER, A., Hydrology and Earth System Science, 14, 2010, p. 2085. 15.SILILO, O.T.N., SAAYMAN, I.C., Groundwater vulnerability to pollution in urban catchments, Report to Water Research Commision, 2001, 51p.

16.KORBEL, K.L., HOSE G.C., Hydrobiologia, 661, 2011, p. 329.

17.VAZQUEZ-SUNE, E., Urban Groundwater. Barcelona city. Study Case, Ph.D. Thesis, Polytechnic University of Catalunya, Barcelona, Spain, 2003

18. PAPADATU, C.P., BORDEI, M., ROMANESCU, G., SANDU, I., Rev. Chim. (Bucharest), 67, no. 9, 2016, p. 1728.

19. MUSCALU, O.M., NEDEFF, V., CHITIMUS, A.D., SANDU, I.G., PARTAL, E., MOSNEGUTU, E., SANDU, I., RUSU, D.I., Rev. Chim. (Bucharest), 69, no. 11, 2018, p. 4006.
20. IACOBAN, C., RISCA, I.M., ROIBU, C., CIORNEA, E.T., NECULA, R., ILIEVA, D., SANDU, I., DROCHIOIU, G., Rev. Chim. (Bucharest), 70, no. 3, 2019, p. 753.

21. BODESCU, D., UNGUREANU, G., MORARU, R.A., SANDU, I.G., BEJ INARIU, C., Rev. Chim. (Bucharest), 69, no. 8, 2018, p. 2150.

22. BOCIORT, D., GHERASIMESCU, C., BERARIU, R., BUTNARU, R., BRANZILA, M., SANDU, I., Rev. Chim. (Bucharest), 63, no. 11, 2012, p. 1152.

23. LUPASCU, T., CIOBANU, M., BOTAN, V., SANDU, I.G., DRAGALIN, I., MITINA, T., SANDU, I., Rev. Chim. (Bucharest), 69, no. 11, 2018, p. 3082.

24.HOWARD, K.W.F., GELO, K.K., Intensive groundwater use in urban areas: the case of megacities, A.A. Balkema Publishers, 2, 2003, p. 35. 25.NASRABADI, T., ABBASI MAEDEH, P., nternational J ournal of Environmental Science and Technology, 11, 2014, p. 293.

26.FERRAL, A., SARMIENTO, T.M., ALANIZ, E., FERRAL A., European Scientific Journal, 3, 2014, p. 13.

27.MATO, R.R.A.M., Groundwater pollution in urban Dar es Salaam, Tanzania: assessing vulnerability and protection priorities Eindhoven: Technische Universiteit Eindhoven, 2002, 216p.

28*** Master Plan for Water - "Extension and rehabilitation of water and wastewater in Bacau", 2014, http://www.csjbacau.ro/fisiere/ attach/1501_48_Cap_10_Rev2-p1.pdf (in Romanian, on-line at 10.02.2017).

29.KUROSAWA, K., KAZUHIKO, E., MASAKAZU, T., JAHIRUDDIN, M., ABU, Z.M., MOSLEHUDDIN, M., ZULFIKAR, R., Communications in Soil Science and Plant Analysis, 39, 2008, p. 1467.

30.RAZOW SKA-JAWOREK, L., Calcium and Magnesium in Groundwater, Occurrence and significance for human health, Library of Congress Cataloging-in-Publication Data, Netherlands, 2014, 221p. 31.WASSERMAN, G.A., LIU, X., PARVEZ, F., AHSAN H., LEVY, D., FACTORLITVAK, P., KLINE, J., GEEN, A., SLAVKOVICH, V., LOLACONO, N.J., CHENG, Z., ZHENG, Y., GRAZIANO, J.H., Environmental Health Perspectives, 114, 2006, p. 124

32.KUEN-SONG, L., CHANG, N.B., CHUANG FINE, T.D., Science and Technology of Advanced Materials, 8, 2008, p. 1.

33.MUSCALU (PLESCAN), O.M., NEDEFF, V., SANDU, I.G., PARTAL, E., MOSNEGUTU, E., BARSAN, N., SANDU, I., RUSU, D., Rev. Chim.(Bucharest), 70, no. 5, 2019, p. 1726.

34.ADUMITROAEI, M.V., GAVRILOAIEI, T., SANDU, A.V., IANCU, G.O., Rev. Chim. (Bucharest), 67, no. 12, 2016, p. 2530.

$35 . * * *$, Law no. 458 of 8 J uly 2002 regarding drinking water quality, republished, as amended.http://www.rowater.ro/dasiret/Legislatie/ LEGE\%20\%20apei\%20\%20107\%20din\%201996\%20actualizata.pdf (in Romanian) (on-line at 10.02.2017).

Manuscript received: 6.06 .2019 